\title{
Recent trends in research on heavy-metal contamination in the sea
}

\author{
G. W. Bryan \\ Marine Biological Association of the United Kingdom, the Laboratory, Citadel Hill; \\ Plymouth PL1 2PB, U. K.
}

\begin{abstract}
Recent trends in the study of metal contamination in the sea are reviewed. Aspects of contamination which are considered include the input of metals to the sea and their deposition in the sediments, the influence of environmental and biological factors on the accumulation of metals by the biota and the use of organisms as indicators of contamination. Laboratory studies on the biological effects of metals and the problem of monitoring effects in the field are discussed. The importance of the metabolism of metals by the biota is stressed since it is relevant to the adaptation of organisms to chronic contamination and to the attainment of very high levels in some commercial species. Finally, the abatement of contamination is discussed.
\end{abstract}

\section{INTRODUCTION}

Stimulated by factors such as the mercury problem and the development of rapid analytical techniques there has over the past 10 years been a spectacular increase in research on heavy-metal contamination in the sea. Heavy metals are of course natural constituents of the marine environment, albeit sometimes at very low levels, and 11 at least ( $\mathrm{Fe}, \mathrm{Cu}, \mathrm{Zn}, \mathrm{Co}, \mathrm{Mn}, \mathrm{Cr}, \mathrm{Mo}, \mathrm{V}, \mathrm{Se}, \mathrm{Ni}, \mathrm{Sn}$ ) appear to be biologically essential. As metalloproteins or metal-protein complexes they occur in enzymes and respiratory pigments, for example, and may have a structural role in polychaete jaws (cf. O'Dell \& Campbell, 1971; Bryan \& Gibbs, 1979). As a result, studies on metal contamination encounter the problem of distinguishing between natural levels and those which are enhanced from anthropogenic sources and may, since metals are demonstrably toxic, produce undesirable effects.

Although from a public health aspect, $\mathrm{Hg}, \mathrm{Cd}$ and $\mathrm{Pb}$ are considered the most hazardous metals and the first two occur on various black lists, several others including $\mathrm{Cu}, \mathrm{Zn}, \mathrm{Ag}$ and $\mathrm{Cr}$ may be of equal or greater hazard to marine biota.

The object of this paper is to review briefly recent ideas about various aspects of the problem of heavy-metal contamination in the sea.

\section{THE FATE OF HEAVY METALS IN THE SEA}

Metals from anthropogenic sources reach the sea via rivers and outfalls, atmospheric fallout, dumping, marine mining and drilling, and from ships. With the increasing availability of information it has become possible to compare the magnitude of natural 
and anthropogenic inputs; for example, Goldberg et al. (1977) concluded that anthropogenic inputs to Narragansett Bay exceeded natural levels by factors of 79 for $\mathrm{Cu}, 56$ for $\mathrm{Pb}$ and 21 for $\mathrm{Zn}$. In some areas the relative importance of different routes of input has been assessed; thus Cambray et al. (1979) showed that the atmospheric inputs of most heavy metals to the North Sea equalled in magnitude those from the River Rhine. Release of metals to the atmosphere raises the possibility of global contamination and a recent assessment (Nriagu, 1979) suggests that global emissions of $\mathrm{Cd}$ (smelting) and $\mathrm{Pb}$ (petrol) exceed natural inputs by well over an order of magnitude. There is evidence suggesting that whereas contamination from other sources tends to be local, atmospheric inputs may have enhanced surface sea-water concentrations of metals including $\mathrm{Hg}$ and $\mathrm{Pb}$ on a regional scale (cf. Windom et al., 1975).

\section{Estuarine deposition of metals}

Since some of the most heavily industrialised areas of the world are sited on the banks of estuaries, these waters are particularly at risk from metallic contamination. In the past, metallic wastes have been discharged into rivers and estuaries based on the assumption that they would be carried to the open sea and dispersed. The truth of the matter is somewhat different and Turekian (1977) has emphasised the efficiency of estuaries as traps where heavy metals are deposited.

Two of the most important components in the deposition process are $\mathrm{Fe}$ and the humic materials which stabilize it and other colloidal constituents in river water (cf. Sholkovitz, 1978). The increase in salinity and sometimes $\mathrm{pH}$ during estuarine mixing leads to the flocculation of iron oxides, the associated humic substances and other materials such as clays, which are then deposited together with their adsorbed trace metals (cf. Davies \& Leckie, 1978). Deposition is often assisted by biological processes such as the production of faeces or pseudofaeces by filter feeders; indeed, in the oceans, the residence times of many metals are primarily controlled by faecal deposition (Cherry et al., 1978).

Examples in Figure 1 show the "soluble" concentrations of $\mathrm{Fe}, \mathrm{Cu}, \mathrm{Zn}$ and $\mathrm{Mn}$ change during estuarine mixing in Restronguet Creek, a branch of the Fal estuary system, which receives acid metalliferous mining wastes via the River Carnon. The initial fall in concentrations is the result of dilution with uncontaminated water from another river, but the cross-hatched areas below the theoretical lines for simple mixing of sea water and river water show the degree of flocculation of the different metals; whereas Fe is almost completely removed from "solution" and $\mathrm{Cu}$ largely so, $\mathrm{Mn}$ and $\mathrm{Zn}$ exhibit far less tendency to be removed. A comparison between concentrations in the inflowing river (largely in solution, pH 3.9) and the Creek sediments is shown in Table 1, and the degree of retention of metals by the sediments, assuming that Fe is $100 \%$ retained, is also shown and compared with values from other areas. The high degree of retention of $\mathrm{Pb}$ and As may relate to their adsorption by oxides of Fe or, as is more likely for $\mathrm{Cu}$, by the associated humic materials. Possibly by virtue of their high concentrations in the river $\mathrm{Mn}$ and $\mathrm{Zn}$ show little retention, as also does Cd which forms strong chloride complexes in sea water and is not readily removed from solution (cf. Sholkovitz, 1978).

Although the behaviour of Fe in Figure 1 is commonly found, the degree of removal (cross-hatched areas) of other metals varies considerably between estuaries (cf. Beau- 

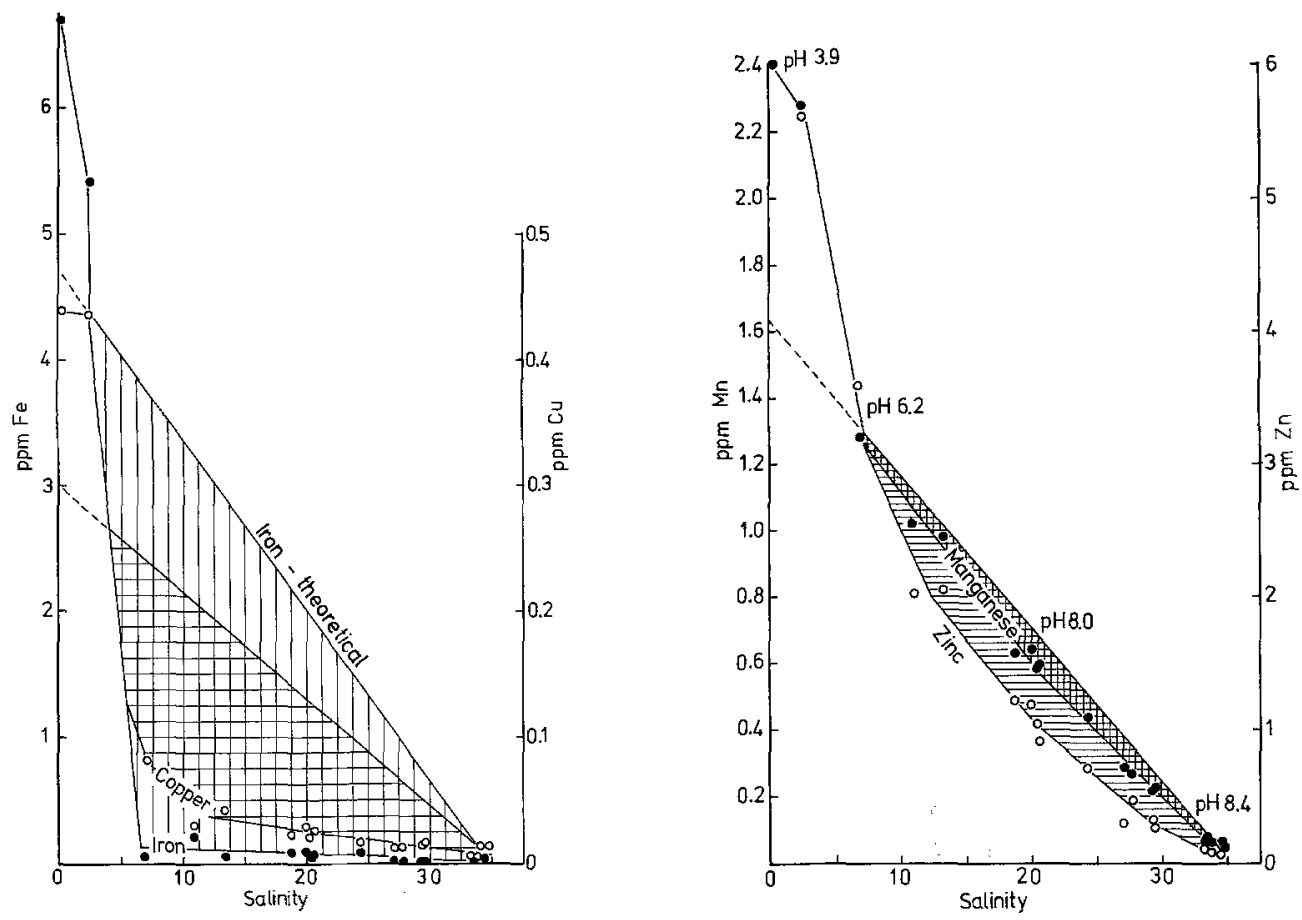

Fig. 1. Restronguet Creek: relations between salinity of water and "soluble" concentrations of four metals. Shaded areas below lines for simple dilution indicate degree of removal of metal from "solution":

lieu: Holliday \& Liss, 1976; Rhine: Duinker \& Nolting, 1978). Indeed, in some estuaries such as the Tamar, concentrations of $\mathrm{Mn}, \mathrm{Zn}$ and $\mathrm{Cu}$ have been observed to peak at intermediate salinities, suggesting remobilization from the sediments or desorption from suspended particles (Bryan \& Hummerstone, 1973; Morris et al., 1978). Redox conditions are particularly relevant to the remobilization of metals from sediments; reducing conditions tend to promote the solubilization of $\mathrm{Mn}$ and $\mathrm{Fe}$, whereas oxidising conditions appear conducive not only to the release of $\mathrm{Cd}, \mathrm{Cu}, \mathrm{Ni}, \mathrm{Pb}$ and $\mathrm{Zn}(\mathrm{Lu} \& \mathrm{Chen}, 1977)$ but also to the microbiological methylation of $\mathrm{Hg}$ which is suspected to be the original source of methyl mercury in marine organisms (cf. Fagerström \& Jernelöv, 1973; Bartlett et al., 1978). The remobilization of metals in estuarine sediment is no guarantee that they will reach the sea since, as Turekian (1977) has pointed out, released metals are quite likely to be carried upstream by the estuarine circulation and redeposited. The deposition of very high concentrations of heavy metals in the sediments of many estuaries (and other confined areas) provides a sink for continued contamination even in the absence of further input and demonstrates clearly the unsuitability of estuaries for heavy metal disposal.

\section{Availability of metals for bioaccumulation}

It is not proposed to discuss the mechanisms of metal absorption by the biota (cf. Bryan, 1979) but rather to consider the influence on uptake of different metallic forms. Some of the earliest studies on this aspect were concerned with the formulation of more 
Table 1. Relation between metal concentrations in Carnon River and Restronguet Creek sediment

\begin{tabular}{|c|c|c|c|c|c|c|}
\hline As & $\mathrm{Cd}$ & $\mathrm{Cu}$ & $\mathrm{Fe}$ & $\mathrm{Mn}$ & $\mathrm{Pb}$ & $\mathrm{Zn}$ \\
\hline \multicolumn{7}{|c|}{ Total concentration in River Carnon (ppb) } \\
\hline 160 & 22 & 615 & 7310 & 957 & 40 & 7585 \\
\hline \multicolumn{7}{|c|}{ Total concentration in Restronguet Creek sediment (ppm) } \\
\hline $1080^{*}$ & $3^{*}$ & 3190 & 60900 & 403 & 379 & 2400 \\
\hline \multicolumn{7}{|c|}{ Percentage retention of river input by sediment assuming $\mathrm{Fe}=100 \%$} \\
\hline 81 & 1.6 & 62 & 100 & 5 & 114 & 3.8 \\
\hline \multicolumn{7}{|c|}{ Percentage retention by southeastern USA estuaries (Windom, 1976) } \\
\hline - & 17 & - & 100 & 64 & - & - \\
\hline \multicolumn{7}{|c|}{ Percentage retention in Chesapeake Bay (Helz, 1976) } \\
\hline- & 22 & 20 & 89 & 26 & 23 & 26 \\
\hline * Thornt & et al. $(1975$ & & & & & \\
\hline
\end{tabular}

deadly antifouling paints. For example, it was shown that the greater toxicity of alkyl than inorganic $\mathrm{Hg}$ compounds to crustaceans probably results because their greater lipid solubility facilitates rapid penetration of the epidermal cell walls (cf. Corner \& Rigler, 1958). Recent work has confirmed these observations on $\mathrm{Hg}$ in various phyla (cf. Pentreath, 1976a; Fowler et al., 1978) and studies have been extended to inorganic and organic species of other metals. Since the culture media often contain chelators, a number of studies have been concerned with the influence of natural and synthetic complexing agents on metal accumulation by phytoplankton: for example Sunda \& Guillard (1976) showed that in such media the availability of $\mathrm{Cu}$ is reduced, the concentrations in the cells being related to the cupric ion activity of the water and not the total $\mathrm{Cu}$ concentration. On the other hand, the uptake of $\mathrm{Cu}$ by the polychaete Cirriformia spirabrancha was unaffected by dissolved yellow organic matter (Milanovich et al., 1976) and in Mytilus edulis George \& Coombs (1977) observed that complexation of Cd with EDTA, alginic acid, humic acid or pectin actually doubled the rate of uptake and the final concentration achieved. Others have been concerned with the influence on uptake of inorganic forms of metals; for example, Fowler \& Benayoun (1976) showed that Se was absorbed more readily as selenite than selenate by $M$. galloprovincialis and studies on the uptake of $\mathrm{Cu}, \mathrm{Cd}, \mathrm{Pb}$ and $\mathrm{Zn}$ in $M$. edulis by Phillips (1976) showed that only $\mathrm{Cu}$ uptake was influenced by the presence of the other metals.

Although metals in solution are often in biologically readily available forms, the much higher concentrations in other phases such as particulates and food organisms often renders them far more important as sources of metals in marine animals. It is hardly surprising that the dietary matrix should influence absorption and Pentreath (1976b), for example, found that $80-93 \%$ of methyl $\mathrm{Hg}$ was retained from a diet of Nereis by the plaice Pleuronectes platessa but only 4-42\% from Mytilus. Similarly, Luoma \& Jenne (1977) showed that the availability of sediment-bound metals to the deposit-feeding bivalve Macoma balthica was very dependent on the composition of particles to which the metals were adsorbed.

Although we know that the bioaccumulation of metals and presumably their toxicity is governed by their form, the recognition and measurement of various species in the field has proved very difficult. In sea water work on metal speciation is only now moving 
Table 2. Some properties of biological indicators of heavy-metal contamination

\begin{tabular}{|c|c|c|c|c|c|c|c|c|}
\hline \multirow[t]{2}{*}{ Species } & \multirow[t]{2}{*}{$\begin{array}{l}\text { Feeding } \\
\text { type }\end{array}$} & \multirow[t]{2}{*}{ Substrate } & \multirow[t]{2}{*}{$\begin{array}{l}\text { Estuarine } \\
\text { tolerance } \\
\text { Spooner \& } \\
\text { Moore (1940) } \\
\text { Upstream limit } \\
\text { in Tamar } \\
\text { Estuary (km } \\
\text { from mouth) }\end{array}$} & \multicolumn{5}{|c|}{$\begin{array}{l}\quad \text { Use as indicator } \\
+\quad \text { Appears to act as indicator } \\
++ \text { Particularly good accumulator } \\
? \quad \text { Doubt about use } \\
\mathrm{R} \text { Definite regulatory ability } \\
\text { () Months for transplanted organisms } \\
\text { to equilibriate with new environ- } \\
\text { ment }\end{array}$} \\
\hline & & & & $\mathrm{Ag}$ & $\mathrm{Cd}$ & $\mathrm{Cu}$ & $\mathrm{Cr}$ & $\mathrm{Hg}$ \\
\hline $\begin{array}{l}\text { Ascophyllum } \\
\text { nodosum }\end{array}$ & - & rock & 11 & & $\begin{array}{l}+ \\
\text { (New }\end{array}$ & $\underset{\text { tis }}{+}$ & $\begin{array}{l}\text { elate } \\
\text { ue } \mathrm{m}\end{array}$ & $\begin{array}{c}+ \\
\text { to new } \\
\text { y never }\end{array}$ \\
\hline $\begin{array}{l}\text { Fucus } \\
\text { vesiculosus }\end{array}$ & - & rock & 21 & + & + & + & + & + \\
\hline $\begin{array}{l}\text { Mytilus } \\
\text { edulis }\end{array}$ & filter & rock & 15 & $?^{6}$ & + & $\begin{array}{c}\stackrel{211}{11}^{(>5 \mathrm{~m} ?)}\end{array}$ & + & $\begin{array}{c}+ \\
(\sim 3 \mathrm{~m})\end{array}$ \\
\hline $\begin{array}{l}\text { Ostrea } \\
\text { edulis }\end{array}$ & filter & $\begin{array}{l}\text { sediment/ } \\
\text { stones }\end{array}$ & 10 & & $\begin{array}{c}+ \\
(>5 \mathrm{~m})\end{array}$ & $\begin{array}{c}++ \\
(>5 \mathrm{~m} ?)\end{array}$ & & \\
\hline $\begin{array}{l}\text { Cerastoderma } \\
\text { edule }\end{array}$ & filter & sediment & 13 & + & + & + & & \\
\hline $\begin{array}{l}\text { Scrobicularia } \\
\text { plana }\end{array}$ & deposit & sediment & 18 & $\begin{array}{c}+ \\
(8 \mathrm{~m})\end{array}$ & $\underset{(>12 \mathrm{~m})}{+}$ & $\begin{array}{c}? \\
(8 \mathrm{~m})\end{array}$ & + & + \\
\hline $\begin{array}{l}\text { Macoma } \\
\text { balthica }\end{array}$ & deposit & sediment & 15 & + & + & $?$ & + & + \\
\hline $\begin{array}{l}\text { Nereis } \\
\text { diversicolor }\end{array}$ & $\begin{array}{l}\text { deposit/ } \\
\text { omnivore }\end{array}$ & sediment & 23 & + & + & + & & $\begin{array}{l}+ \\
\operatorname{span} \text { of }\end{array}$ \\
\hline $\begin{array}{l}\text { Littorina } \\
\text { littorea }\end{array}$ & herbivore & $\begin{array}{l}\text { rock/ } \\
\text { sediment }\end{array}$ & 11 & + & + & $++\mathrm{R}$ & $?$ & \\
\hline $\begin{array}{l}\text { Littorina } \\
\text { obtusata }\end{array}$ & herbivore & $\begin{array}{l}\text { rock/weed/ } \\
\text { sediment }\end{array}$ & 11 & + & ++ & ++ & & \\
\hline $\begin{array}{l}\text { Patella } \\
\text { vulgata }\end{array}$ & herbivore & rock & 8 & + & $\begin{array}{l}++ \\
(3 m ?)\end{array}$ & $\begin{array}{c}+ \\
(>3 \mathrm{~m})\end{array}$ & & \\
\hline $\begin{array}{l}\text { Nucella } \\
\text { lapillus }\end{array}$ & carnivore & rock & 5 & + & $\begin{array}{c}++ \\
(>4 \mathrm{~m})\end{array}$ & $\begin{array}{c}++ \\
(>4 \mathrm{~m})\end{array}$ & & \\
\hline
\end{tabular}

References: 1. Haug et al. (1974); 2. Melhuus et al. (1978); 3. Myklestad et al. (1978); 4. Bryan \& Hummerstone (1973); 5. Morris \& Bale (1975); 6. Bryan \& Hummerstone (1977); 7. Seeliger \& Edwards (1977); 8. unpublished; 9. Boyden (1975); 10. Boyden (1977); 11. Phillips (1977); 12. Davies \& Pirie (1978); 13. Young et al. (1979); 14. Simpson (1979); 15. Majori et al. (1978);

from the field of theory into that of reality with the aid of anodic stripping voltammetry and specific ion electrodes, for example. In the case of sediments, recognition of various forms depends mainly on chemical extraction procedures largely inherited from soil chemists. These methods are certainly useful but are rarely if ever specific for a particular form and descriptions of sediment fractions as "adsorbed metals" or "organically bound" are operational rather than true descriptions of the extracts.

Because the speciation of metals in the environment is largely unknown it is 
Influence of increasing size

Concentration rises $(+)$ falls $(-)$

remains constant $(0)$

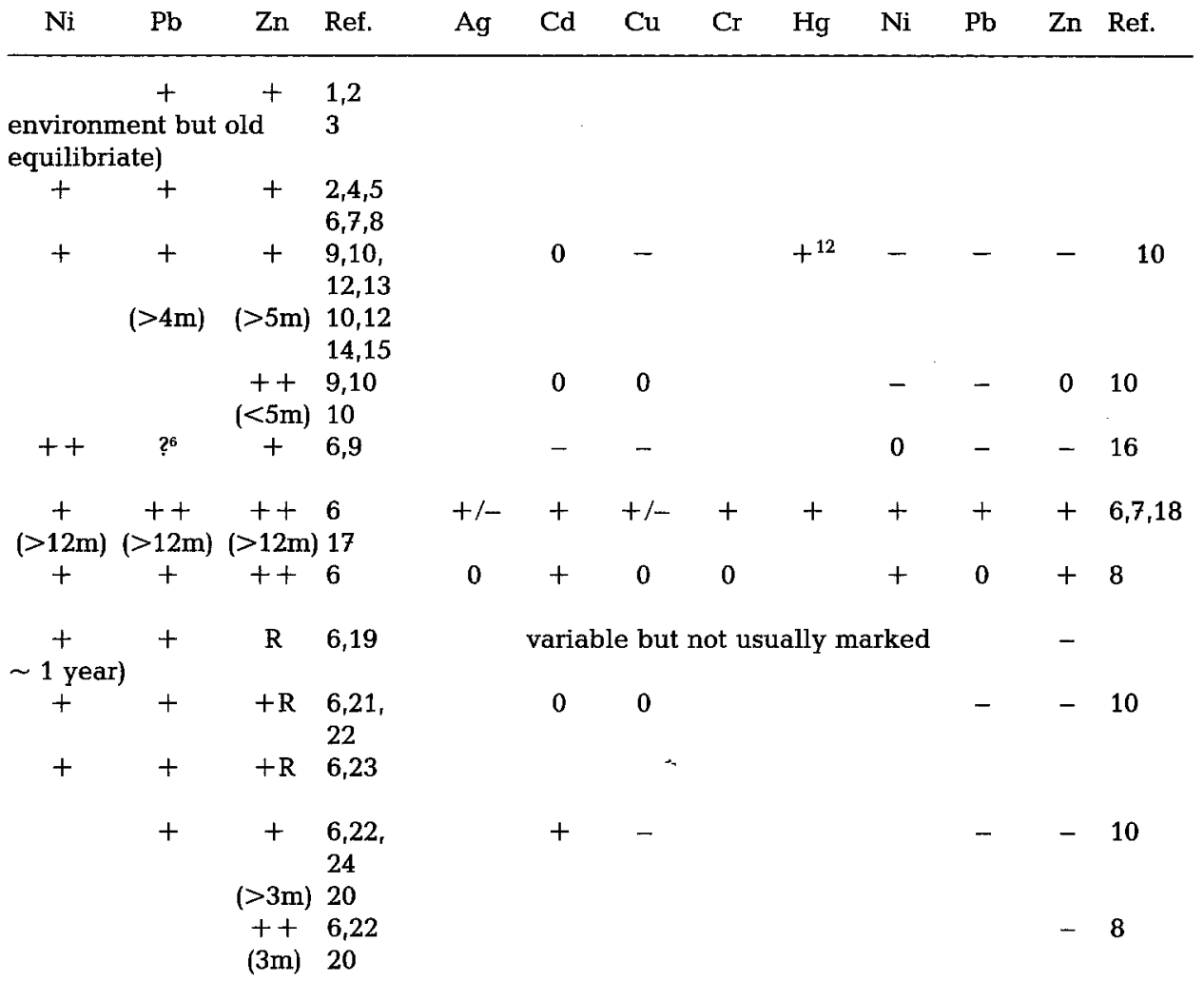

16. Boyden (1974); 17. Bryan \& Hummerstone (1978); 18. Bryan \& Uysal (1978); 19. Bryan (1974); 20. Stenner \& Nickless (1974); 21. Bryan (1979); 22. Nickless et al. (1972); 23. Young (1975); 24. Preston et al. (1972)

frequently difficult to relate laboratory observations on metal uptake (or toxicity) to the field situation. As a result, field studies on the uptake and loss of metals have recently been conducted by transferring animals between contaminated and uncontaminated areas (Table 2). While this type of experiment suffers from lack of control, the long periods often required for equilibration with the new environment certainly emphasise the difficulty of drawing conclusions from short-term laboratory experiments. Field studies have also been used to identify factors controlling the availability of metals. 
Luoma \& Bryan $(1978,1979)$ compared the concentrations of various metals in the deposit-feeding bivalve Scrobicularia plana with the concentrations in chemical extracts of surface sediments. The study covered a large number of estuaries so that the animals came from sediments which varied widely in total metal concentrations and in the abundance of metal-binding substrates such as iron and manganese oxides and organic matter. In the case of $\mathrm{Pb}$, the concentration in the animal was almost directly proportional to the $\mathrm{Pb} / \mathrm{Fe}$ ratio in $\mathrm{IN} \mathrm{HCl}$ or $25 \%$ acetic acid extracts of surface sediment, indicating that the binding of $\mathrm{Pb}$ by oxides of $\mathrm{Fe}$ is an important control on its availability to the animal.

\section{Biological factors in bioaccumulation}

Although metal speciation has a great influence on the bioaccumulation of heavy metals, the metabolism of the metal in the organism has an important influence on the concentrations ultimately achieved; both factors are of course influenced by environmental parameters such as salinity, temperature and so on. If an organism absorbs metals at a rate proportional to the environmental concentration there are at least three possible types of relation between the concentrations achieved by the tissues and those of the environment. (1) The organism excretes the metal at a rate proportional to the body burden and therefore the concentration in the body is proportional to environmental availability and usually remains fairly constant or tends to fall with increasing age (e..g. Mytilus edulis, Table 2). (2) The organism has limited powers of excretion and tends to store absorbed metals. In this case the concentration in the organism may still be directly proportional to environmental availability but, unless it grows fast enough to dilute the metal, the level in the body tends to increase with age (e. g. Scrobicularia plana, Table 2). (3) The organism is able to increase the efficiency of excretion in response to increased absorption and therefore the concentration in the body does not increase in proportion to environmental availability (cf. Table 2 for examples of these regulating organisms). Generally speaking, the more highly evolved forms including fish and decapod crustaceans tend to be the best regulators and the essential metals such as $\mathrm{Zn}$ and $\mathrm{Cu}$ are better regulated than the non-essential such as $\mathrm{Cd}$ and especially $\mathrm{Hg}$.

\section{Food chains and biomagnification}

In the context of the passage of metals along food chains, it is of some importance whether or not a predator regulates metals and whether its diet consists of organisms which do or do not regulate. For example, flounder, Platichthys flesus, from the Severn Estuary having a diet of Macoma balthica (non-regulator) contained higher levels of $\mathrm{Zn}$ than those having a diet of crustaceans and small fish which tend to regulate $\mathrm{Zn}$ (Hardisty et al., 1974). Some years ago it was tacitly assumed by many people that all contaminants are biologically magnified in their passage along food chains. It is not difficult to find examples where animals contain higher metal concentrations than their diet (cf. Cd in two non-regulators, Littorina obtusata and Fucus vesiculosus in Table 5). However, if one looks at the concentrations of metals over the whole spectrum of organisms from phytoplankton to fish and marine mammals, the only metal for which there is evidence of general bioamplification is mercury or, more specifically, methyl 
mercury which does not appear to be regulated by any of the lower organisms and the majority of fish. It was suggested Bryan $\left._{z} 1979\right)$ that the development of demethylation processes in a few predatory fish species and marine mammals is an evolutionary response to biomagnification.

\section{INDICATORS OF METALLIC CONTAMINATION}

Although sea-water analysis certainly has a place in the detection of metallic contamination, it has until recently proved difficult to obtain meaningful results in oceanic areas because of additional contamination during sampling (cf. Bruland et al., 1979). In addition, the variability of levels, particularly in stratified tidal estuaries makes it difficult to obtain an integrated picture without considerable sampling effort. By comparison, analyses of sediments are easy and have provided valuable information not only about recent metallic inputs but also, from dated cores, about the history of contamination (cf. Goldberg et al., 1977).

However, analyses of water and sediments are rarely carried out with regard to biological availability and therefore, since this parameter is one of the prerequisites for pollution, there is a strong argument for the analysis of biological indicators. Such indicators should preferably be good accumulators of metals, of reasonable size and should reflect changes in environmental availability; thus organisms having an ability to regulate metals are unsuitable. Other desirable properties are that the organism should be widely distributed, common, accessible, easily recognised, relatively stationary, available at all times of year and, for estuarine purposes, sufficiently tolerant of low salinities and high suspended solids to penetrate a reasonable distance upstream (cf. Phillips, 1977). The properties of some intertidal benthic organisms which have proved useful as indicators in the United Kingdom are summarised in Table 2 and an indication of the relative merits of some of these species as accumulators is given in Table 3 . Because different species have different distributions ranging from rocky shores to muddy estuaries and absorb metals from different sources, there is no universal indicator

Table 3. Comparison of metal accumulation in indicator species from a site $2 \mathrm{~km}$ up East Looe Estuary contaminated with $\mathrm{Ag}$ and $\mathrm{Pb}$. Highest concentrations are underlined

\begin{tabular}{|c|c|c|c|c|c|c|c|c|c|}
\hline \multirow[t]{2}{*}{ Species } & \multirow{2}{*}{$\begin{array}{l}\text { Mean dry weight } \\
\text { soft parts } \\
\text { (g) }\end{array}$} & \multicolumn{8}{|c|}{ ppm dry tissue } \\
\hline & & $\mathrm{Ag}$ & $\mathrm{Cd}$ & $\mathrm{Cr}$ & $\mathrm{Cu}$ & $\mathrm{Hg}^{* *}$ & $\mathrm{Ni}$ & $\mathrm{Pb}$ & $\mathrm{Zn}$ \\
\hline Fucus vesiculosus & - & 0.7 & 1.1 & 1.9 & 12 & 0.09 & 11.3 & 17 & 190 \\
\hline Mytilus edulis & 0.24 & 0.2 & 2.3 & 2.5 & 9 & 0.39 & 2.6 & 45 & 113 \\
\hline Cerastoderma edule & 0.28 & 2.4 & 0.7 & 1.9 & 10 & 0.26 & $\underline{54}$ & 5.3 & 54 \\
\hline Scrobicularia plana & 0.15 & 56.4 & 1.2 & $\underline{3.3}$ & 300 & 0.47 & $\overline{14} .5$ & $\underline{189}$ & $\underline{1120}$ \\
\hline Macoma balthica & 0.04 & $\underline{81.9}$ & 0.2 & $\underline{3.3}$ & $\underline{338}$ & - & 6.9 & 61 & 1010 \\
\hline Nereis diversicolor & 0.02 & $\overline{4.2}$ & 0.4 & $\overline{0.3}$ & $\overline{60}$ & 0.11 & 3.5 & 25 & 258 \\
\hline Littorina littorea & 0.18 & 30.0 & 1.6 & 0.5 & 154 & 0.37 & 2.8 & 17 & 232 \\
\hline Patella vulgata & 0.53 & 5.6 & 5.6 & 0.5 & 18 & 0.26 & 2.3 & 30 & 145 \\
\hline Nucella lapillus* & 0.20 & 4.2 & $\underline{16}$ & 5.6 & 141 & $\underline{0.92}$ & 4.1 & 7.1 & 520 \\
\hline
\end{tabular}




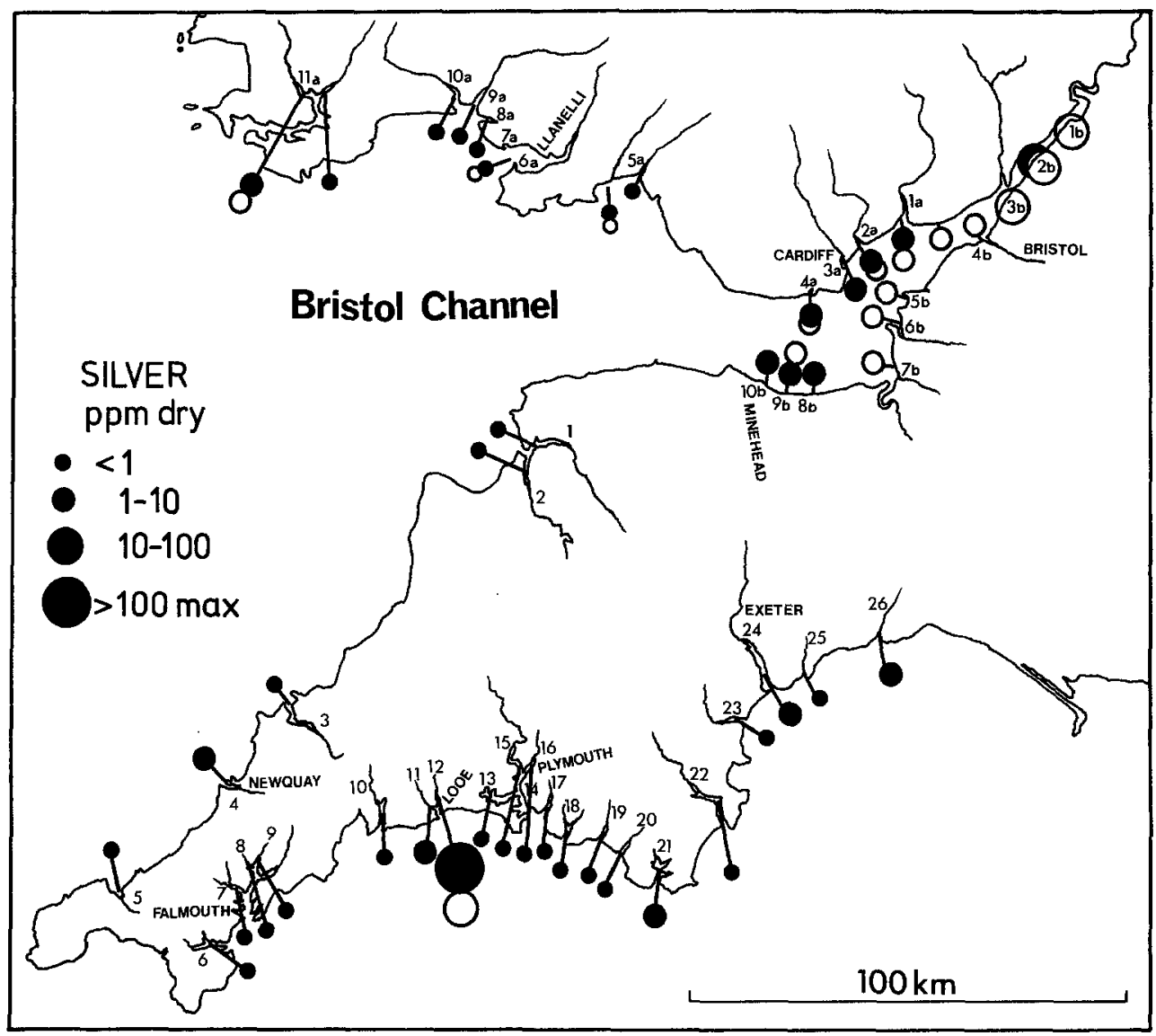

Fig. 2. South-west Britain: geographical distribution of Ag in whole soft parts of Scrobicularia plana. Open circles are equivalent levels in Macoma balthica, the concentration ranges above being divided by 0.59 . Results are for individual sites in Severn (1a-4a, 1b-10b) but in estuaries 1-26 and 5a-11a are mean values along estuary. Estuary 7 is Restronguet Creek

organism. Any reasonable monitoring programme should therefore involve analyses of several species (e. g. seaweed, filter feeder, deposit feeder) to try and assess contamination in different forms. Table 3 illustrates how contamination with particulate Ag was readily available to the deposit-feeding bivalves Scrobicularia plana and Macoma balthica but not to Mytilus edulis and Fucus vesiculosus two commonly used indicators. Because of influences such as those of size (Table 2) and condition on metal levels in organisms, their use calls for uniformity of sampling. With Scrobicularia it was found necessary to analyse animals of 4-cm shell length collected from mid-tide level in either spring or autumn to avoid the breeding season (cf. Fig. 2). Partly because it has been the subject of so much study Mytilus appears to have more than its share of problems as an indicator, particularly with regard to obtaining organisms of comparable size, condition and so on at different sites. However, some of these problems have been circumvented with the use of caged, cultivated mussels of known age as indicators of Hg contamination (Davies \& Pirie, 1978). 
Generally speaking, the best biological indicators of metallic contamination are not the most commercially valuable species. Fish are generally monitored from the public health aspect, but for most metals are poor indicators of environmental contamination. However, they appear unable to regulate $\mathrm{Hg}$ (largely in the methyl form) and are arguably the best indicators of environmental contamination with this metal, if size is taken into account (cf. Phillips, 1977). A linear relation between $\mathrm{Hg}$ levels in sea water and those in the muscle of various teleosts has been demonstrated by Gardner (1978); concentration factors (wet basis) ranged from $2.9 \times 10^{3}$ in the least contaminated to 10.6 $\times 10^{3}$ in the most contaminated inshore waters, possibly reflecting the tendency for concentration-size regressions for fish to steepen in contaminated areas (cf. Renzoni, 1976).

\section{EFFECTS OF HEAVY METALS}

\section{Experimental studies}

There is no doubt that the $\mathrm{LC}_{50}$ (median lethal concentration) approach to heavymetal toxicity has provided a wealth of information about the effects of different metals on different species and has revealed the many factors, biological, chemical and environmental which modify toxicity. Even after long exposure, $\mathrm{LC}_{50}$ concentrations rarely fall in the ranges observed in the most contaminated waters. Experiments with some larval organisms provide exceptions and Calabrese et al. (1977) found an 8-10 day $\mathrm{LC}_{50}$ of $16 \mathrm{ppb}$ of $\mathrm{Cu}$ (SW usually $<1 \mathrm{ppb}$ ) for larvae of the bivalve Mercenaria mercenaria. Although this approach has relevance to small organisms, which may accumulate metals rapidly, it has been shown to be patently unsatisfactory for larger organisms. Here, absorption of the metal (and hence an effective dose) is often so slow that sometimes only ridiculously high concentrations are effective in toxicity tests having death as the end point. An example in Table 4 for Ctenodrilus serratus shows that although the 96 hour $\mathrm{LC}_{50}$ for $\mathrm{Cr}$ was $4.33 \mathrm{ppm}$ compared with 0.09 for $\mathrm{Hg}$, the concentrations which in time affected reproduction were equal at $0.05 \mathrm{ppm}$. The much lower toxicity of $\mathrm{Cr}$ in the $\mathrm{LC}_{50}$ test probably reflects its slower uptake by the worm and hence the slower attainment of an effective dose. Rate of uptake is certainly one of the important factors on which the relative toxicity of different metals depends: Table 4 shows how the toxicities of metals to Nereis diversicolor are closely related to uptake rates measured with radionuclides. Although the dose to an organism is very important it is often difficult to define. It is not simply the total level in the body since this will include metals in immobilised forms. The rate of intake is important because this determines whether the organism's detoxification mechanism can cope or not: one of the main adaptations found in metal-tolerant strains of various species is a lower permeability, although very high concentrations of immobilised metals may be found.

Some of the factors which influence toxicity (e. g. form of metal, influence of other chemicals, salinity and temperature) may be effective because they change the rate of absorption or excretion. However, less than optimum living conditions (e. g. low food supply, low oxygen level, low salinity) which stress the organism are also important and are additive to the effect of the metal.

In the search for effects at realistic concentrations, increasing numbers of studies 
Table 4. Toxicity of metals to two polychaete species

\begin{tabular}{|c|c|c|c|c|}
\hline \multirow[t]{2}{*}{ Element } & \multicolumn{2}{|c|}{ Ctenodrilus serratus (Reish, 1978) } & \multicolumn{2}{|c|}{ Nereis diversicolor $(50 \% \mathrm{SW})$} \\
\hline & $\begin{array}{c}96 \text { hour } \mathrm{LC}_{50} \\
\text { (ppm) }\end{array}$ & $\begin{array}{l}\text { Significant suppres- } \\
\text { sion of reproduction } \\
(\mathrm{ppm})\end{array}$ & $\begin{array}{l}192 \text { hour } \mathrm{LC}_{50} \\
(\mathrm{ppm})\end{array}$ & $\begin{array}{l}\text { Rate of absorption } \\
\text { from } 0.1 \mathrm{ppm} \\
\text { (ppm dry wgt/day) }\end{array}$ \\
\hline $\mathrm{Hg}$ & 0.09 & 0.05 & $>0.1$ & 52 \\
\hline $\mathrm{Cu}$ & 0.3 & 0.1 & 0.27 & 16 \\
\hline $\mathrm{Ag}$ & - & - & 0.5 & 9 \\
\hline $\mathrm{Cr}(6)$ & 4.3 & 0.05 & 10 & 5 (approx. $^{*}$ ) \\
\hline $\mathrm{Zn}$ & 7.1 & 0.5 & 30 & 1.4 \\
\hline $\mathrm{Cd}$ & $>20$ & 2.5 & 100 & 0.4 \\
\hline
\end{tabular}

have considered the sublethal effects of metals and have progressively increased in sophistication. They include multiparameter physiological, biochemical and histopathological studies on exposed fish (cf. Calabrese et al., 1975), studies on the most vulnerable stages in life cycles such as the eggs and early larval stages of fish (cf. Blaxter, 1977), factorial experiments demonstrating the combined effects of metal, salinity and temperature on larval development of shrimp (cf. McKenney \& Neff, 1979), experiments with laboratory cultures (e. g. polychaetes, Reish, 1978) and of course the controlled ecosystem or plastic-bag experiments (cf. Steele, 1979). Even this sub-lethal work has frequently failed to demonstrate effects at realistic metal concentrations. Taylor $(1977 \mathrm{a}, \mathrm{b})$ summarised information on the sub-lethal effects of $\mathrm{Hg}$ and $\mathrm{Cd}$ and found that the lowest levels producing an effect were $0.1 \mathrm{ppb} \mathrm{Hg}(\mathrm{SW} \sim 0.02 \mathrm{ppb})$ and 1 $\mathrm{ppb} \mathrm{Cd}(\mathrm{SW} \sim 0.1 \mathrm{ppb})$ but that $90 \%$ of the results were in the ranges $>5 \mathrm{ppb} \mathrm{Hg}$ and $>$ $50 \mathrm{ppb} \mathrm{Cd}$. Some of the effects observed at realistic levels will be considered briefly.

Calabrese et al. (1975) studied the effects of exposure for 60 days to $5 \mathrm{ppb}$ of $\mathrm{Cd}$ on the flounder Pseudopleuronectes americanus. Oxygen consumption was depressed in excised gill tissue but no effects were observed on various haematological parameters such as plasma protein level and plasma osmolality. In addition, no histopathological effects were observed, but Gould (1977) showed that synthesis of Zn metalloenzymes was stimulated so that although under attack from $\mathrm{Cd}$ their functions could continue at a near-normal rate. Adaptation to exposure was also observed by Dawson et al. (1977) who showed that although the oxygen consumption of excised gill tissue from the striped bass Morone saxatilis was depressed after 30 days exposure to $0.5 \mathrm{ppb}$ of $\mathrm{Cd}$ it had returned to normal after 90 days. However, as Gould (1977) has pointed out, adaptive processes involving enzymic changes will be a drain on metabolic energy.

The possibility of effects of metals on fecundity and reproduction is of particular environmental importance and some species have been found to be very sensitive. For example, Moraitou-Apostolopoulou \& Verriopoulos (1979) showed that egg production in the copepod Acartia clausi was inhibited by only $1 \mathrm{ppb}$ of $\mathrm{Cu}(\mathrm{SW}<1 \mathrm{ppb})$, and in the copepod Pseudodiaptomus coronatus Paffenhöfer \& Knowles (1978) found that $5 \mathrm{ppb}$ of Cd reduced the rate of reproduction by $50 \%$ but had no effect on growth, food conversion and so on. There is a considerable literature on the effects of low levels of metals on the growth of phytoplankton populations in culture (Davies, 1978), although it is often 
difficult to extrapolate the results to the field. However, studies on natural populations of phytoplankton have shown them to be quite sensitive and Davis \& Sleep (1979) showed that the carbon fixation rate was depressed by $15 \mathrm{ppb}$ of $\mathrm{Zn}$ ( $\mathrm{SW} \sim 1 \mathrm{ppb}$ ), a level often exceeded in contaminated areas.

The most ambitious experimental studies on the effects of metals have been the controlled ecosystem experiments carried out in enclosures in the Saanich Inlet. Results from these and experiments at Loch Ewe have been reviewed by Steele (1979). Although some effects were apparent following additions of $1 \mathrm{ppb}$ of $\mathrm{Hg}$ or $10 \mathrm{ppb}$ of $\mathrm{Cu}$ to the enclosures, it proved difficult in some cases to separate the effects of the metals from the added stresses of enclosure. In fact, Steele points out that large tank experiments containing a simple phytoplankton, Tellina, plaice food chain were more sensitive to metals than the more natural ecosystems, effects being observed on phytoplankton at 3 $\mathrm{ppb}$ of $\mathrm{Cu}$ and on plaice at $0.1 \mathrm{ppb}$ of $\mathrm{Hg}$.

It can be concluded that in some species effects have been observed experimentally at concentrations coming within the range of values for some contaminated estuaries, fjords and coastal regions. However, the concentrations in such areas are not generally so high that effects in the field are likely to be immediately obvious.

\section{Effects of metals in two contaminated estuaries}

There are remarkably few examples in the literature concerning deleterious effects on the marine environment which can unequivocably be attributed to metal contamination (e.g. Minamata Bay, Japan). Obviously the places where effects should be sought are those where residue analyses have shown there to be high levels of contamination. Two United Kingdom estuaries coming into this category are considered below.

\section{Restronguet Creek}

Restronguet Creek (Fig. 2) is a branch of the Fal Estuary system and is heavily contaminated with metals (Fig. 1, Table 1). The Creek is about $4 \mathrm{~km}$ long, almost dries out at low tide and has been contaminated for over 200 years. Examples of $\mathrm{Cu}$ and $\mathrm{Zn}$ concentrations in organisms approaching their upstream limits of distribution are given in Table 5 and ratios showing their enhancement above normal values are also given. Enhancement for $\mathrm{Cu}$ varies from about two orders of magnitude in seaweed and polychaete worms to low levels in the crab and flounder where regulation probably occurs. Regulation probably explains the variability in Zn enhancement both directly and because some predators may feed on organisms which already regulate. Although copper is one of the most toxic metals and the influence of $\mathrm{Zn}$ and other metals in Table 5 might be expected to be additive, the variety of species found in the Creek clearly results from their great ability to handle high concentrations of $\mathrm{Cu}$ and $\mathrm{Zn}$. For example, this is inherent in oysters where the immobilization of $\mathrm{Cu}$ (and $\mathrm{Zn}$ ) in a granular form in the amoebocytes leaves the animals green in colour and inedible but otherwise unaffected (cf. George et al., 1978). Other species appear to have adapted by exposure to metals. Carcinus maenas from the upper Creek were particularly tolerant to $\mathrm{Zn}$, most of the larger Creek animals in one experiment being unaffected by $10 \mathrm{ppm}$ over a period of 38 days whereas $50 \%$ of the normal crabs died within 6 days. The more tolerant animals were generally less permeable to zinc and perhaps better equipped to excrete it; 
however, the induction of $\mathrm{Zn}$ metallothionein may also be involved, having been observed in other species of crabs by Olafson et al. (1979). In the polychaete Nereis diversicolor tolerance to both $\mathrm{Cu}$ and $\mathrm{Zn}$ appears to be genetically based (Bryan, 1976). Tolerance to $\mathrm{Cu}$ observed in Fucus vesiculosus from this estuary might also have a genetic basis since this has been observed in other seaweeds (Russell \& Morris, 1970). Although having a lower initial growth rate $F$. vesiculosus from the Creek was able to continue growing in water containing $0.1 \mathrm{ppm}$ of $\mathrm{Cu}$ which prevented growth in weed from other estuaries (Fig. 3). Analyses of the weed at the beginning and end of the experiments suggest that the tolerant weed is probably less permeable to $\mathrm{Cu}$ and that this coupled with growth dilution helps to limit the concentration.

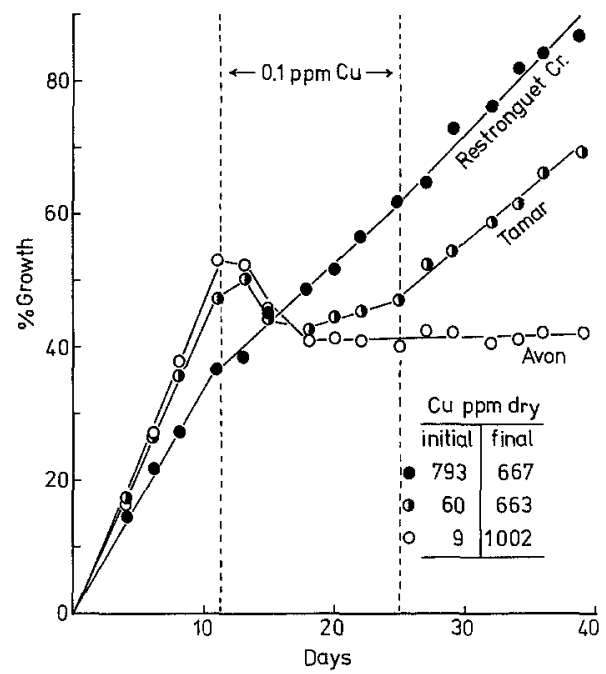

Fig. 3. Fucus vesiculosus. Effect of $\mathrm{Cu}$ on growth and concentrations in plants from three contrasting estuaries. Each line represents three plants of about $3-\mathrm{cm}$ initial length $\left(17.5 \mathrm{~S} \%{ }^{\circ}, 13^{\circ} \mathrm{C}\right.$, continuous light, no added nutrients)

Since there appear to be no non-metallic contaminants of any significance in the Creek any effects on the distribution of the biota should be attributable to heavy metals. The effects are certainly not as clear-cut as might be expected, the most obvious being the absence of Scrobicularia plana from large areas of the intertidal muds where, under normal conditions, it would account for an appreciable fraction of the total biomass.

\section{Severn Estuary - Bristol Channel}

As a result of industrial processes such as smelting, the waters of the Severn Estuary (Fig. 2) are appreciably contaminated with Cd (1.4-9.4 ppb) and other metals (Abdullah \& Royle, 1974). Detectable Cd contamination extends for some $200 \mathrm{~km}$ and Table 5 illustrates the enhancement of both $\mathrm{Cd}$ and Ag levels in species collected towards their upstream limits of distribution. Enhancement of $\mathrm{Cd}$ in all species is consistently high, appearing to reflect quite closely the enhancement in the water (say $5 \mathrm{ppb}$ divided by $0.1 \mathrm{ppb}=50$ ) and the inability of most species to regulate Cd levels. The apparent indifference of these organisms to such high Cd levels resides in most cases in the 


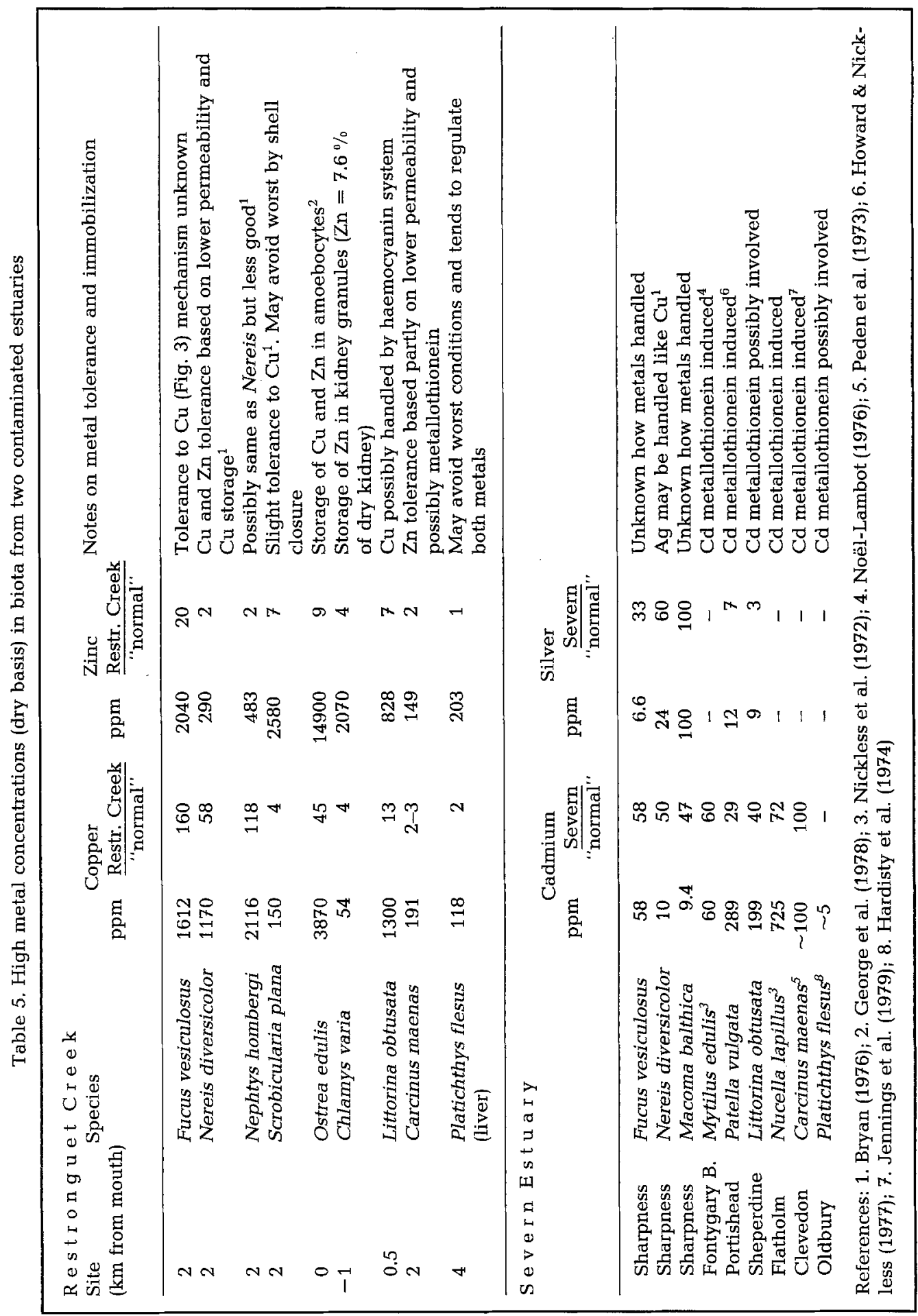


induction of metallothioneins (Table 5). Enhancement of Ag was particularly obvious in the burrowing species but how it is handled in Macoma balthica is unknown.

A study of faunistic records covering the last 30 years (Mettam, 1979) indicates that the total number of species in the estuary has remained relatively constant and there is no evidence for long-term environmental changes. As with Restronguet Creek, however, contamination in the area is long standing (cf. Clifton \& Hamilton, 1979) and there is no certain base line with which to compare.

\section{Monitoring the effects of heavy metals}

Although deleterious effects may be observed in the field, the complexity of contamination in many areas makes it difficult to unequivocally relate effects to specific pollutants. Since it demonstrates exposure, and also presumably the utilization of energy by the organism to detoxify metals, residue analysis is an obvious preliminary to any attempt to solve this problem. Even this approach requires care to make it specific; for example, analysis of fish muscle, as opposed to perhaps viscera or gills, is unlikely to show whether a fish has been exposed to high levels of $\mathrm{Zn}$ or $\mathrm{Cu}$.

In Restronguet Creek it was reasonable to assume that ecological effects were related to metals but impossible from analyses and simple toxicity tests alone to specify with any certainty whether $\mathrm{Cu}$ or $\mathrm{Zn}$ was most important. However, the study illustrated in Figure 3 demonstrates the development of a very marked difference between the tolerance to $\mathrm{Cu}$ of Fucus from the Creek and that of other populations: the difference for $\mathrm{Zn}$ was much less obvious, indicating that $\mathrm{Cu}$ had the more important impact on this species. Luoma (1977) has advocated the study of differences in tolerance between normal and polluted populations towards specific toxins as a means of identifying which contaminants are having most impact. All inducible tolerance mechanisms (e. g. metallothioneins) may not be completely metal specific but tolerance having a genetic basis is usually (but not always) specific (cf. Bryan, 1976; Brown, 1978).

Various studies following the reciprocal transfer of organisms between uncontaminated and contaminated areas have proved useful in assessing effects. For example, changes in metal residue levels and condition in transferred Scrobicularia plana were used to assess what had appeared to be a deleterious effect of $\mathrm{Pb}$ and other metals (Bryan \& Hummerstone, 1978). Concentration gradients in the field often provide suitable conditions for studies relating effects to environmental levels; for example, Shore et al. (1975) showed that there was a possible correlation between increasing levels of Cd in the limpet Patella vulgata along the Severn Estuary - Bristol Channel and reduced ability to utilize glucose (cf. Table 5).

The use of bioassays to assess water quality is normally non-specific. However, with the hydroid Campanularia flexuosa the influence of metals in water of low quality from the Bristol Channel was measured by the improvement observed when they were removed from the water with Chelex resin (Stebbing, 1979). Other studies in the same sea area have demonstrated the occurrence of deleterious effects in mussels as inferred by various physiological and biochemical indices of condition (cf. Bayne et al., 1979) and the high incidence of diseased specimens (Lowe \& Moore, 1979). At present these studies are largely unspecific, but attempts are being made to arrive at indices that might measure the effects of single classes of pollutant. 


\section{Effects on mammals and man}

Generally speaking, there is little evidence for the deleterious effects of heavy metals on marine mammals. However, Stoneburner (1978) has suggested that Hg may have caused the stranding of pilot whales based on the observation that $\mathrm{Hg}$ : Se ratios in the livers of some whales far exceeded the 1:1 molar ratio usually observed: this normally seems to result from the storage of $\mathrm{Hg}$ as mercuric selenide granules following the demethylation of methyl $\mathrm{Hg}$ absorbed from the fish diet (Martoja \& Viale, 1977). It has been observed that $\mathrm{Hg}$ levels in the livers of seals tend to increase with age, particularly in contaminated areas, whereas concentrations in muscle remain low. Roberts et al. (1976) observed about 1 ppm (wet) in muscle from the common seal Phoca vitulina compared with more than $100 \mathrm{ppm}$ in the liver of the oldest animals.

Studies on natives of the Canadian Arctic who eat seals have shown them to have somewhat increased levels of $\mathrm{Hg}$ in hair and blood but no evidence of poisoning has been discovered (cf. Smith \& Armstrong, 1978). As far as I am aware, with the exception of Minamata disease there is no evidence that marine foodstuffs have caused any permanent form of metal poisoning in humans. However, the dietary intake rates of metals such as $\mathrm{Hg}$ and $\mathrm{Cd}$ regarded as tolerable are so low that they can readily be exceeded by eating contaminated seafood (cf. FAO/WHO, 1972).

\section{Abatement of contamination}

Fujiki (1973) reported that whereas in 1959 the bivalve Venus japonica from Minamata Bay contained 178 ppm (dry) of $\mathrm{Hg}$ this had fallen to only a few ppm in 1970 following removal of the $\mathrm{Hg}$ sources. However, levels of $\mathrm{Hg}$ in the sediments remain as high as $100 \mathrm{ppm}$ at some sites and are gradually being dispersed to other areas (Kumagai \& Nishimura, 1978). Following a reduction of $95-98 \%$ in the $\mathrm{Hg}$ output from an Italian chlor-alkali plant it was observed that in 28-29 months the concentration in the crab Pachygrapsus marmoratus fell by $78 \%$ and the fall in other species ranged from $20-31 \%$ (Renzoni, 1976). It was noted that complete recovery would probably be delayed by the large amounts of $\mathrm{Hg}$ built up in the sediments. Of course, it is not always so easy to stop the input of wastes. For example, examination of a dated sediment core from the Tamar Estuary by Clifton \& Hamilton (1979) showed that levels of $\mathrm{Cu}, \mathrm{Zn}$ and $\mathrm{Pb}$ in the sediments rose sharply following a peak of metalliferous mining in the mid-nineteenth century and have remained constant for the past 100 years. This has been caused by continual input from the weathering of spoil heaps and, although the estuary is regarded as unpolluted, concentrations of metals in the biota are abnormally high.

Acknowledgement. Some of the work described in this paper was supported by the Department of the Environment under Contract DGR 480/51.

\section{LITERATURE CITED}

Abdullah, M. I. \& Royle, L. G., 1974. A study of the dissolved and particulate trace elements in the Bristol Channel. - J. mar. biol. Ass. U. K. 54, 581-597.

Bartlett, P. D., Craig, P. J. \& Morton, S. F., 1978. Total mercury and methyl mercury levels in British estuarine and marine sediments. - Sci. total Environ. 10, 245-251. 
Bayne, B. L., Moore, M. N., Widdows, J., Livingstone, D. R. \& Salkeld, P., 1979. Measurement of the responses of individuals to environmental stress and pollution: studies with bivalve molluscs. Phil. Trans. R. Soc. (B) 286, 563-581.

Blaxter, J. H. S., 1977. The effect of copper on the eggs and larvae of plaice and herring. - J. mar. biol. Ass. U. K. 57, 849-858.

Boyden, C. R., 1974. Trace element content and body size in molluscs. - Nature, Lond, 251, 311-314.

Boyden, C. R., 1975. Distribution of some trace metals in Poole Harbour, Dorset. - Mar. Pollut. Bull. $6,180-187$.

Boyden, C. R., 1977. Effect of size upon metal content of shellfish. - J. mar. biol. Ass. U. K. 57, 675-714.

Brown, B. E., 1978. Lead detoxification by a copper-tolerant isopod. - Nature, Lond. 276, 388-390.

Bruland, K. W., Franks, R. P., Knauer, G. A. \& Martin, J. H., 1979. Sampling and analytical methods for the determination of copper, cadmium, zinc and nickel at the nanogram per liter level in sea water. - Analytica chim. Acta 105, 233-245.

Bryan, G. W., 1974. Adaptation of an estuarine polychaete to sediments containing high concentrations of heavy metals. In: Pollution and physiology of marine organisms. Ed. by F. J. Vernberg \& W. B. Vernberg. Acad. Press, New York, 123-135.

Bryan, G. W., 1976. Some aspects of heavy metal tolerance in aquatic organisms. In: Effects of pollutants on aquatic organisms. Ed. by A. P. M. Lockwood. Cambridge Univ.'Press, Cambridge 7-34.

Bryan, G. W., 1979. Bioaccumulation of marine pollutants. - Phil. Trans. R. Soc. (B) 286, 483-505.

Bryan, G. W. \& Gibbs, P. E., 1980. Zinc - a major inorganic component of nereid polychaete jaws. J. mar. biol. Ass. U. K. 59, 969-973.

Bryan, G. W. \& Hummerstone, L. G., 1973. Brown seaweed as an indicator of heavy metals in estuaries in south-west England. - J. mar. biol. Ass. U. K. 53, 705-720.

Bryan, G. W. \& Hummerstone, L. G., 1977. Indicators of heavy-metal contamination in the Looe Estuary (Cornwall) with particular regard to silver and lead. - J. mar. biol. Ass. U. K. 57, 75-92.

Bryan, G. W. \& Hummerstone, L. G., 1978. Heavy metals in the burrowing bivalve Scrobicularia plana from contaminated and uncontaminated estuaries. - J. mar. biol. Ass. U. K. 58, 401-419.

Bryan, G. W. \& Uysal, H., 1978. Heavy metals in the burrowing bivalve Scrobicularia plana from the Tamar Estuary in relation to environmental levels. - J. mar. biol. Ass. U. K. 58, 89-108.

Calabrese, A., McInnes, J. R., Nelson, D. A. \& Miller, J. E., 1977. Survival and growth of bivalve larvae under heavy-metal stress. - Mar. Biol. 41, 179-184.

Calabrese, A., Thurberg, F. P., Dawson, M. A. \& Wenzloff, D. R., 1975. Sublethal physiological stress induced by cadmium and mercury in the winter flounder, Pseudopleuronectes americanus. In: Sublethal effects of toxic chemicals on aquatic animals. Ed. by J. H. Koeman \& J. J. T. W. A. Strik. Elsevier, Amsterdam, 15-21.

Cambray, R. S., Jefferies, D. F. \& Topping, G., 1979. The atmospheric input of trace elements to the North Sea. - Mar. Sci. Commun. 5, 175-194.

Cherry, R. D., Higgo, J. J. W. \& Fowler, S. W., 1978. Zooplankton faecal pellets and element residence times in the ocean. - Nature, Lond. 274, 246-248.

Clifton, R. J. \& Hamilton, E. I., 1979. Lead-210 chronology in relation to levels of elements in dated sediment core profiles. - Estuar. coast. mar. Sci. 8, 259-269.

Corner, E. D. S. \& Rigler, F. H., 1958. The modes of action of toxic agents. III. Mercuric chloride and N-amylmercuric chloride on crustaceans. - J. mar. biol. Ass. U. K. 37, 85-96.

Davies, A. G., 1978. Pollution studies with marine plankton. Part II. Heavy metals. - Adv. mar. Biol. 15, 381-508.

Davies, A. G. \& Sleep, J. A., 1979. Photosynthesis in some British coastal waters may be inhibited by zinc pollution. - Nature, Lond. 277, 292-293.

Davies, I. M. \& Pirie, J. M., 1978. The mussel Mytilus edulis as a bio-assay organism for mercury in sea water. - Mar. Pollut. Bull. 9, 128-132.

Davies, J. A. \& Leckie, J. O., 1978. Effect of adsorbed complexing ligands on trace metal uptake by hydrous oxides. - Environ. Sci. Technol. 12, 1309-1315.

Dawson, M. A., Gould, E., Thurberg, F. P. \& Calabrese, A., 1977. Physiological response of juvenile striped bass, Morone saxatilis, to low levels of cadmium and mercury. - Chesapeake Sci. 18, 353-359. 
Duinker, J. C. \& Nolting, R. F., 1978. Mixing, removal and mobilizätion of 'trace metals in the Rhine Estuary. - Neth. J. Sea Res, 12, 205-223.

Fagerström, T. \& Jernelöv, A., 1973. Formation of methyl mercury from pure mercuric sulphide in aerobic organic sediment. - Wat. Res. 5, 121-122.

F. A. O./W. H. O. Joint Expert Committee on Food Additives, 1972, - Tech. Rep. Ser. Wld Hlth Org. $505,11-16$.

Fowler, S. W. \& Benayoun, G., 1976. Influence of environmental factors on selenium flux in two marine invertebrates. - Mar. Biol. 37, 59-68.

Fowler, S. W., Heyraud, M. \& LaRosa, J., 1978. Factors affecting methyl and inorganic mercury dynamics in mussels and shrimp. - Mar. Biol. 46, 267-276.

Fujiki, M., 1973. The transitional condition of Minamata Bay and the neighbouring sea polluted by factory waste water containing mercury. In: Advances in water pollution research. Ed. by S. H. Jenkins. Pergamon Press, Oxford, 6, 905-920.

Gardner, D., 1978. Mercury in fish and waters of the Irish Sea and other United Kingdom fishing grounds. - Nature, Lond. 272, 49-51.

George, S. G. \& Coombs, T. L., 1977. The effects of chelating agents on the uptake and accumulation of cadmium by Mytilus edulis. - Mar. Biol. 39, 261-268.

George, S. C. Pirie, B. J. S., Cheyne, A. R., Coombs, T. L. \& Grant, P. T., 1978. Detoxication of metals by marine bivalves: an ultrastructural study of the compartmentation of copper and zinc in the oyster Ostrea edulis. - Mar. Biol. 45, 147-156.

Goldberg, E. D., Gamble, E., Griffin, J. J. \& Koide, M., 1977. Pollution history of Narrangansett Bay as recorded in its sediments. - Estuar. coast mar. Sci. 5, 549-561.

Gould, E., 1977. Alteration of enzymes in winter flounder, Pseudopleuronectes americanus, exposed to sublethal amounts of cadmium chloride. In: Physiological responses of marine biota to pollutants. Ed. by F. J. Vernberg, A. Calabrese, F. P. Thurberg \& W. B. Vernberg. Acad. Press, New York 209-224.

Hardisty, M. W., Kartar, S. \& Sainsbury, M., 1974. Dietary habits and heavy metal concentrations in fish from the Severn Estuary and Bristol Channel. - Mar. Pollut. Bull. 5, 61-63.

Haug, A., Melsom, S. \& Omang, S., 1974. Estimation of heavy metal pollution in two Norwegian fjord areas by analysis of the brown alga Ascophyllum nodosum. - Environ. Pollut. 7, 179-192.

Helz, G. R., 1976. Trace element inventory for the northern Chesapeake Bay with emphasis on the influence of man. - Geochim. cosmochim. Acta, 40, 573-580.

Holliday, L. M. \& Liss, P. S., 1976. The behaviour of dissolved iron, manganese and zinc in the Beaulieu Estuary, S. England. - Estuar. coast. mar. Sci. 4, 349-353.

Howard. A. G. \& Nickless, G., 1977. Heavy metals complexation in polluted molluscs. 1. Limpets (Patella vulgata and Patella intermedia). - Chem.-biol. Interactions 16, 107-114.

Jennings, J. R, Rainbow, P. S. \& Scott, A. G., 1979. Studies on the uptake of cadmium by the crab Carcinus maenas in the laboratory. II. Preliminary investigation of cadmium-binding proteins. Mar. Biol. 50, 141-149.

Kumagai, M. \& Nishimura, H., 1978. Mercury distribution in seawater in Minamata Bay and the origin of particulate mercury. - J. oceanogr. Soc. Japan. 34, 50-56.

Lowe, D. M. \& Moore, M. N., 1979. The cytology and occurrence of granulocytomas in mussels. Mar. Pollut. Bull. 10, 137-141.

Lu, J. C. S. \& Chen, K. Y., 1977. Migration of trace metals in the interfaces of sea water and polluted surficial sediments. - Environ. Sci. Technol. 11, 174-182.

Luoma, S. N., 1977. Detection of trace contaminant effects in aquatic ecosystems. - J. Fish. Res. Bd Can. 34, 436-439.

Luoma, S. N. \& Bryan, G. W., 1978. Factors controlling the availability of sediment-bound lead to the estuarine bivalve Scrobicularia plana. - J. mar. biol. Ass. U. K. 58, 793-802.

Luoma, S. N. \& Bryan, G. W., 1979. Trace metal bioavailability: modeling chemical and biological interactions of sediment-bound zinc. In: Chemical modeling in aqueous systems. Ed. by E. A. Jenne. American Chemical Society, Washington, D. C., 577-609.

Luoma, S. N. \& Jenne, E. A., 1977. The availability of sediment-bound cobalt, silver and zinc to a deposit-feeding clam. In: Biological implications of metals in the environment. Ed. by $\mathrm{H}$. Drucker \& R. E. Wildung. U. S. N. T. I. S., Springfield, 213-231 (Conf-750929). 
Majori, L., Nedoclan, G., Modonutti, G. B. \& Daris, F., 1978. Methodological researches on the phenomenon of metal accumulation in Mytilus galloprovincialis and on the possibility of using biological indicators as test-organisms of marine metal pollution. - Revue int. Océanogr. méd. $49,81-87$.

Martoja, R. \& Viale, D., 1977. Accumulation de granules de séléniure mercurique dans le foie d'Odontocétes (Mammiféres, Cétacés): un méchanism possible de détoxication du méthylmercure par le sélénium. - C. r. hebd. Séanc. Acad. Sci., Paris (D) 285, 109-112.

McKenney, C. L. \& Neff, J. M., 1979. Individual effects and interactions of salinity, temperature and zinc on larval development of the grass shrimp Palaemonetes pugio. 1. Survival and developmental duration through metamorphosis. - Mar. Biol. 52, 177-188.

Melhuus, A., Seip, K. L., Seip, H. M. \& Myklestad, S., 1978. A preliminary study of the use of benthic algae as biological indicators of heavy metal pollution in Sørfjorden, Norway. - Environ. Pollut. $15,101-107$.

Mettam, C., 1979. Faunal changes in the Severn Estuary over several decades. - Mar. Pollut. Bull. $10,133-136$.

Milanovich, F. P., Spies, R., Guram, M. S. \& Sykes, E. E., 1976. Uptake of copper by the polychaete Cirriformia spirabrancha in the presence of dissolved yellow organic matter of natural origin. Estuar. coast. mar. Sci. 4, 585-588.

Moraitou-Apostolopoulou, M. \& Verriopoulos, G., 1979. Some effects of sub-lethal concentrations of copper on a marine copepod. - Mar. Pollut. Bull. 10, 88-92.

Morris, A. W. \& Bale, A. J., 1975. The accumulation of cadmium, copper, manganese and zinc by Fucus vesiculosus in the Bristol Channel. - Estuar. coast. mar. Sci. 3, 153-163.

Morris, A. W., Mantoura, R. F. C., Bale, A. J. \& Howland, R. J. M., 1978. Very low salinity regions of estuaries: important sites for chemical and biological reactions. - Nature, Lond. 274, 678-680.

Myklestad, S., Eide, I. \& Melsom, S., 1978. Exchange of heavy metals in Ascophyllum nodosum (L.) Le Jol. in situ by means of transplanting experiments. - Environ. Pollut. 16, 277-284.

Nickless, G., Stenner, R. \& Terrille, N., 1972. Distribution of cadmium, lead and zinc in the Bristol Channel. - Mar. Pollut. Bull. 3, 188-190.

Noël-Lambot, F., 1976. Distribution of cadmium, zinc and copper in the mussel Mytilus edulis. Existence of cadmium-binding proteins similar to metallothioneins. - Experientia 32, 324-326.

Nriagu, J. O., 1979. Global inventory of natural and anthropogenic emissions of trace metals to the atmosphere, - Nature, Lond. 279, 409-411.

O'Dell, B. L. \& Campbell, B. J., 1971. - Compreh. Biochem. 21, 179-266.

Olafson, R. W., Sim, R. G. \& Boto, K. G., 1979. Isolation and chemical characterization of the heavy metal-binding protein metallothionein from marine invertebrates. - Comp. Biochem. Physiol. 62 (B), 407-416.

Paffenhöfer, G. A. \& Knowles, S. C., 1978. Laboratory experiments on feeding, growth and fecundity of and effects of cadmium on Pseudodiaptomus. - Bull. mar. Sci. 28, 574-580.

Peden, J. D., Crothers, J. H., Waterfall, C. E. \& Beasley, J., 1973. Heavy metals in Somerset marine organisms. - Mar. Pollut. Bull, 4, 7-9.

Pentreath, R. J., 1976a. The accumulation of organic mercury from sea water by the plaice Pleuronectes platessa L. - J. exp. mar. Biol. Ecol. 24, 121-132.

Pentreath, R. J., 1976b. The accumulation of mercury from food by the plaice, Pleuronectes platessa L. - J. exp. mar. Biol. Ecol. 25, 51-65.

Phillips, D. J. H., 1976. The common mussel Mytilus edulis as an indicator of pollution by zinc, cadmium, lead and copper. 1. Effects of environmental variables on uptake of metals. - Mar. Biol. 38, 59-69.

Phillips, D. J. H., 1977. The use of biological indicator organisms to monitor trace metal pollution in marine and estuarine environments - a review. - Environ. Pollut. 13, 281-317.

Preston, A., Jefferies, D. F, Dutton, J. W. R., Harvey, B. R. \& Steele, A. K., 1972. British Isles coastal waters: The concentrations of selected heavy metals in sea water, suspended matter and biological indicators - a pilot survey. - Environ. Pollut. 3, 69-82.

Reish, D., 1978. The effects of heavy metals on polychaetous annelids. - Revue int. Océanogr. méd. $49,99-103$.

Renzoni, A., 1976. A case of mercury abatement along the Tuscan coast. 25th Congress and Plenary Assembly of ICSEM. Workshop on Marine Pollution (October 22-23, 1976). Split, Yugoslavia. 
Roberts, T. M., Heppleston, P. B. \& Roberts, R. D., 1976. Distribution of heavy metals in the tissues of the common seal. - Mar. Pollut. Bull. 7, 194-196.

RusselI, G. \& Morris, O. P., 1970. Copper tolerance in the marine fouling alga Ectocarpus siliculosus. - Nature, Lond. 228, 288-289.

Seeliger, U. \& Edwards, P., 1977. Correlation coefficients and concentration factors of copper and lead in sea water and benthic algae. - Mar. Pollut. Bull. 8, 16-19.

Sholkovitz, E. R., 1978. The flocculation of dissolved $\mathrm{Fe}, \mathrm{Mn}, \mathrm{Al}, \mathrm{Cu}, \mathrm{Ni}, \mathrm{Co}$ and $\mathrm{Cd}$ during estuarine mixing. - Earth Planet. Sci. Lett. 41, 77-86.

Shore, R., Carney, G. \& Stygall, T., 1975. Cadmium levels and carbohydrate metabolism in limpets. - Mar. Pollut. Bull. 6, 187-189.

Simpson, R. D., 1979. Uptake and loss of zinc and lead by mussels (Mytilus edulis) and relationships with body weight and reproductive cycle. - Mar. Pollut. Bull. 10, 74-78.

Smith, T. G. \& Armstrong, F. A. J., 1978. Mercury and selenium in ringed and bearded seal tissues from arctic Canada. - Arctic 31, 75-84.

Spooner, G. M. \& Moore, H. B., 1940. The ecology of the Tamar Estuary. Part VI. An account of the macrofauna of the intertidal muds. - J. mar. biol. Ass. U. K. 24, 283-330.

Stebbing, A. R. D., 1979. An experimental approach to the determinants of biological water quality. - Phil. Trans. R. Soc. (B) 286, 465-481.

Steele, J. H., 1979. The uses of experimental ecosystems. - Phil. Trans. R. Soc. (B) 286, 583-595.

Stenner, R. D. \& Nickless, G., 1974. Absorption of cadmium, copper and zinc by dog whelks in the Bristol Channel. - Nature, Lond. 247, 198-199.

Stoneburner, D. L., 1978. Heavy metals in tissues of stranded short-finned pilot whales. - Sci. total Environ. 9, 293-297.

Sunda, W. \& Guillard, R. R. L., 1976. The relationship between cupric ion activity and the toxicity of copper to phytoplankton. - J. mar. Res. 34, 511-529.

Taylor, D., 1977a. A summary of the data on the toxicity of various materials to aquatic life. Vol. 1: Mercury. Imperial Chemical Industries, Brixham, $23 \mathrm{pp}$.

Taylor, D., $1977 \mathrm{~b}$. A summary of the data on the toxicity of various materials to aquatic life. Vol. 2: Cadmium. Imperial Chemical Industries, Brixham, $21 \mathrm{pp.}$

Thornton, I., Watling, H. \& Darracott, A., 1975. Geochemical studies in several rivers and estuaries used for oyster rearing. - Sci. total Environ. 4, 325-345.

Turekian, K. K., 1977. The fate of metals in the oceans. - Geochim. Cosmochim. Acta 41, 1139-1144.

Windom, H. L., 1976. Geochemical interactions of heavy metals in southeastern salt marsh environments. U. S. Environmental Protection Agency. EPA-600/3-76-023.

Windom, H. L., Taylor, F. E. \& Waiters, E. M., 1975. Possible influence of atmospheric transport on the total mercury content of southeastern Atlantic continental shelf surface waters. - Deep Sea Res. 22, 629-633.

Young, D. R., Alexander, G. V. \& McDermott-Ehrlich, D., 1979. Vessel-related contamination of southern California harbours by copper and other metals. - Mar. Pollut. Bull. 10, 50-56.

Young, M. L., 1975. The transfer of ${ }^{65} \mathrm{Zn}$ and ${ }^{59} \mathrm{Fe}$ along a Fucus serratus (L.) - Littorina obtusata (L.) food chain. - J. mar. biol. Ass. U. K. 55, 583-610. 